\title{
Simultaneous determination of organic acids and sugars in fruit juices by High performance liquid chromatography: characterization and differentiation of commercial juices by principal component analysis
}

\section{Deyse Pegorini Rodrigues ${ }^{1}$ (D) Marina Leite Mitterer-Daltoé ${ }^{1}$ (D) Vanderlei Aparecido de Lima (iD $^{1}$ Marcio Barreto-Rodrigues $^{1^{*} \text { (B) }}$ Edimir Andrade Pereira ${ }^{1}$ (D)}

${ }^{1}$ Programa de Pós-graduação em Tecnologia de Processos Químicos e Bioquímicos, Departamento Acadêmico de Química, Universidade Tecnológica Federal do Paraná, 85503-390, Pato Branco, PR, Brasil. E-mail: marciorodrigues@utfpr.edu.br. "Corresponding author.

ABSTRACT: The present research presents an analytical methodology based on High Performance Liquid Chromatography (HPLC) and Principal Component Analyses (PCA) for simultaneous quantification and analytical differentiation of organic acids and sugars in commercial fruit juice samples (orange, grape, apple and tangerine). In addition to the development of the method that generated suitable validation paramters for quantitative analytical applications, the analysis of fourteen commercial samples and the use of Principal Component Analysis indicated the relationship between the constituents and the very constitutional chemical nature of the juice. In general, in grape and apple juices, ascorbic acid was not quantified and the citric acid content was very low; however, the concentrations of fructose and glucose were the highest in both juices. In orange and mandarin orange juices, the content of all analytes, except acorbic acid, did not differ statistically from each other. However, these differed significantly from the others, mainly in relation to sucrose content. Finally, the apple juice samples differed according to the content of fructose and malic acid, the predominant constituint of the apple. Results showed that the simultaneous chromatographic method associated with principal component analysis generated important information about characteristics of commercial juices, with the potential to be used in systems of quality control and identification of adulterations.

Key words: HPLC, principal components analysis, sugars and acid organic, fruit juice.

Determinação simultânea de ácidos orgânicos e açucares em sucos de frutas por Cromatografia líquida de alta eficiência: caracterização e diferenciação de sucos comerciais por análise de componentes principais

RESUMO: O presente trabalho apresenta uma metodologia analítica baseada em Cromatografia Liquida de Alto Desempenho (CLAE) e Análise de Componentes Principais (ACP) para quantificação simultânea e diferenciação analítica de ácidos orgânicos e açúcares em amostras comerciais de suco de frutas (laranja, uva, maçã e tangerina). Além do desenvolvimento do método que gerou parâmetros de validação adequados para aplicações analítica quantitativas, a análise de catorze amostras comerciais e o uso da ACP indicaram a relação entre os analitos e a natureza química constitucional do suco. Em geral, nos sucos de uva e maçã não foi quantificado ácido ascórbico sendo o conteúdo de ácido citrico muito baixo, no entanto, as concentrações de frutose e glicose foram as mais altas em ambos sucos. Nos sucos de laranja e tangerina, o conteúdo de todos os analitos, exceto o ácido ascórbico, não diferiram estatisticamente entre si. No entanto, diferiram significativamente dos demais, principalmente em relação ao conteúdo de sacarose. Finalmente, as amostras de suco de maçã diferiram de acordo com o teor de frutose e ácido málico, constituinte predominante da maçã. Os resultados mostraram que o método comatográfico simultâneo associado à análise de componentes principais gera informações importantes sobre as características dos sucos comerciais, com potencialidade para ser utilizado em sistemas de controle de qualidade e identificação de adulterações. Palavras-chave: HPLC, análise de componentes principais, açúcares e ácidos orgânicos, suco de fruta.

\section{INTRODUCTION}

Brazilian fruit culture represents a segment of agribusiness that produces about 40 million tons per year and occupies an area of 2 million hectares. Much of this production is destined for the fruit juice industry, which has been on the rise in the last decade. Among the various flavors of orange juice, it always stands out, for example in 2019 its production exceeded 375 thousand tons only in the states of São Paulo and in the mining triangle (HORTIFRUTI BRASIL YEARS 2019-2020, 2019).

Industrialized fruit juices are foods that are appreciated throughout the age group of the world population because they are considered healthy, practical, nutritious and delicious foods. This food 
has some naturally occurring components such as organic acids and simple sugars. These constituents are responsible for the flavor of fruits and juices, promoting a strong impact on the sensory quality and some chemical characteristics of this food, such as $\mathrm{pH}$, total acidity, sweetness, microbial stability and general acceptability (CHINNICI et al., 2005; BORSANI et al., 2009; XIE et al., 2009; EYÉGHÉBICKONG et al., 2012; LIMA et al., 2014; DE OLIVEIRA et al., 2014; COSTA et al., 2016).

The main acids present in fruit juice are ascorbic, citric, malic and tartaric. They play an important role in fruit coloring, incluencing flavor, odor, stabilization and anthocyanin content and prolonging the shelf life of fresh fruits and their processed products (MA et al., 2015). Conversely, the group of simple sugars composed of glucose and fructose, besides the disaccharide sucrose are found mainly in fruits and fruit juices (DEMIATE et al., 2002). They are used for human consumption as a source of energy as components in food and beverages, because of their physical properties and their sweet taste.

In the food analysis laboratories, it is common to determine the Total Titratable Acid (TTA) and Total Soluble Solids (TSS) content, which are usually proportional to the acidity of the predominant organic acid and the sugar content; respectively, vary according to the climate, soil, maturation stage and cultivar. However, without the aid of High Performance Liquid Chromatography (HPLC), it is not easy to quantify and separate the complex system that consists of an aqueous mixture of several components in industrialized fruit juices.

The use of chromatography (CLAE) in food analysis is extensively reported in the literature (SCHERER et al., 2008; LIMA et al. 2010; RANGEL et al., 2011; LIMA et al., 2014; ZAKY et al., 2017). This is due to HPLC being an efficient technique, possessing high sensitivity and good reproducibility, besides being precise and attending to several classes of samples, being possible the analysis of both organic and inorganic compounds (ZAKY et al., 2017). In the case of organic compounds it is more used because it has a low cost compared to other methods and the preparation of the samples includes, in most cases, only filtration and dilution (RIZZON \& SGANZERLA, 2007; KRITSUNANKUL et al., 2009; LIMA et al., 2010). However, most of the applications reported in the literature explore the two groups of compounds (organic acids and sugars) separately. For example, CHINNICI et al. (2005) and ZIELINSKI et al. (2014) quantified sugars sucrose, glucose and fructose in apple juices using HPLC. SCHERER et al., (2008) analyzed apple, orange and grape juice and quantified the citric, ascorbic, malic and tartaric acids via reverse phase HPLC. Under similar conditions, LIMA et al. (2014) dosed citric, lactic, acetic, ascorbic, malic and tartaric acids in grape juice.

In order to contribute to the area, the presentresearch presents a suitable chromatographic method for the simultaneous analysis of sugar and organic acids in fruit juices associated to Principal Component Analysis to evaluate the distribution of these constituents in commercial samples from Southern Brazil.

\section{MATERIALS AND METHODS}

\section{Samples}

Forteen samples of commercial juices of different brands (two of apple, six of grape, four of orange and two of tangerine) were purchased in a local market in the city of Pato Branco, PR, Brazil. Samples were subdivided into four groups according to the fruit of origin: orange, grape, tangerine and apple and received the identification codes described in table 1. After identification, the samples were subjected to analysis procedures and kept under freezing at $-18^{\circ} \mathrm{C}$.

\section{Chromatographic analysis \\ The qualitative and quantitative} chromatographic analysis of sugars: sucrose, glucose

Table 1 - Coding of fruit juice samples analyzed.

\begin{tabular}{lc}
\hline Sample & Code \\
\hline Orange juice & Or1, Or2, Or3, Or4 \\
Grape juice & Gr1, Gr2, Gr3, Gr4, Gr5, Gr6 \\
Apple juice & Ap1, Ap2 \\
Tangerine juice & Ta1, Ta2 \\
\hline
\end{tabular}

Ciência Rural, v.51, n.3, 2021. 
and fructose and organic acids: citric, ascorbic, malic and tartaric in industrialized juices was carried out with the aid of the High Performance Liquid Chromatography (HPLC) technique using a Varian brand, model 920-LC (Varian Inc., Walnut Creek, CA, USA). For simultaneous separation of analytes was used an AMINEX HPX-87H column (Bio-Rad, Hecules, CA) and two detectors, the Refractive Index (RI) for sugars and Diodes (DAD) for the acids, the oven temperature being set at $45{ }^{\circ} \mathrm{C}$. The mobile phase consisted of a single solution of sulfuric acid 0.008 mol.L $\mathrm{L}^{-1}$ in isocratic mode with flow of 0.6 $\mathrm{mL} \cdot \mathrm{min}^{-1}$. All samples were analyzed in triplicate and the analytes were identified by comparison (retention time and characteristic absorption) with authentic high purity standards (Supelco and Sigma) and quatified through external standardization. A brief description of these can be seen from the data presented in table 2 .

\section{Validation of the chromatographic method}

The validation of the chromatographic method was performed according to ANVISA (BRASIL, 2003). The linearity was obtained as a function of the calibration curves, which in turn were constructed by plotting the peak area of the compounds under study versus the concentration of the analyte tested, using six concentration ranges of the standard solutions. The curve was constructed from the addition of the mass of each standard to $25 \mathrm{~cm}^{3}$ of ultra pure water in order to obtain a stock solution where the sugar and acid mix was reported at concentrations of 0.500 g. $100 \mathrm{~mL}^{-1}$ and 0.100 g. $100 \mathrm{~mL}^{-1}$ respectively, such concentrations were selected based on background concentrations. From the stock solution, dilutions were performed for lower concentrations, in order to obtain a calibration curve that was subsequently injected in triplicate. The precision of the method was determined based on repeatability and intermediate accuracy. For repeatability analysis, also called intra-run precision, 6 consecutive injections of the standard were performed on the same day with the same instrumentation and analyst. Intermediate precision, known as inter-run precision, was determined by injecting one sample with the same instrument, but with different analysts, within six days. The results are expressed as percentage of coefficient of variation $(\mathrm{CV} \%)$. The limit of detection (LOD) was calculated based on the ratio of 3 times the baseline noise signal. The limit of quantification (LOQ) was determined from the ratio of 10 times the baseline noise signal.

\section{Sample treatment and statistical analysis}

Samples of fruit juices underwent the pre-injection beverage treatment procedure, which consisted of the mobile phase dilution (1:20), filtration in a $0.45 \mu \mathrm{m}$ CHOMAFIX filter, filtration in SEP PACK C18 cartridges for the withdrawal of interferents and finally injection of $20 \mu \mathrm{L}$ of sample into a chromatograph liquid. For the purpose of data interpretation, results were submitted to analysis of variance and the means comparison was done by the Tukey test at $5 \%$ of probability, using the statistical program Sisvar $^{\circledR}$ (FERREIRA, 2011). Principal Component Analysis (PCA) was also performated to relate organic acids and sugars to different types of juices. Statistical analysis was performed in Pirouette ${ }^{\circledR}$ software (Informetrix).

\section{RESULTS AND DISCUSSIONS}

Development and validation of the chromatographic method Figures 1 and 2 show the chromatograms of a solution containing the standard mixture of the citric, malic, ascorbic and tartaric acids (0.100 g.100 $\left.\mathrm{mL}^{-1}\right)$ and sucrose, glucose and fructose $(0.500 \mathrm{~g} .100$ $\left.\mathrm{mL}^{-1}\right)$ using DAD and RI detectors, respectively.

Table 2 - Description, retention time and detection of the organic acid and sugar standards used in the analyzes.

\begin{tabular}{lcccc}
\hline Compound & Molecular formula & Purity (\%) & $\mathrm{t}_{\mathrm{r}}$ & Detection $^{*}$ \\
\hline L-ascorbic acid & $\mathrm{C}_{6} \mathrm{H}_{8} \mathrm{O}_{6}$ & 99.4 & 9.53 & DAD \\
Citric acid & $\mathrm{C}_{6} \mathrm{H}_{8} \mathrm{O}_{7}$ & 99.9 & 7.83 & DAD \\
D-malic & $\mathrm{C}_{4} \mathrm{H}_{6} \mathrm{O}_{5}$ & 99.9 & 9.32 & DAD \\
D-tartaric acid & $\mathrm{C}_{4} \mathrm{H}_{6} \mathrm{O}_{6}$ & 99.2 & DAD \\
Sucrose & $\mathrm{C}_{12} \mathrm{H}_{22} \mathrm{O}_{11}$ & 99.37 & 7.45 & RI \\
Fructose & $\mathrm{C}_{6} \mathrm{H}_{12} \mathrm{O}_{6}$ & 99.0 & 9.58 & RI \\
Glucose & $\mathrm{C}_{6} \mathrm{H}_{12} \mathrm{O}_{6}$ & 99.5 & 8.82 & $\mathrm{RI}$ \\
\hline
\end{tabular}

Ciência Rural, v.51, n.3, 2021. 


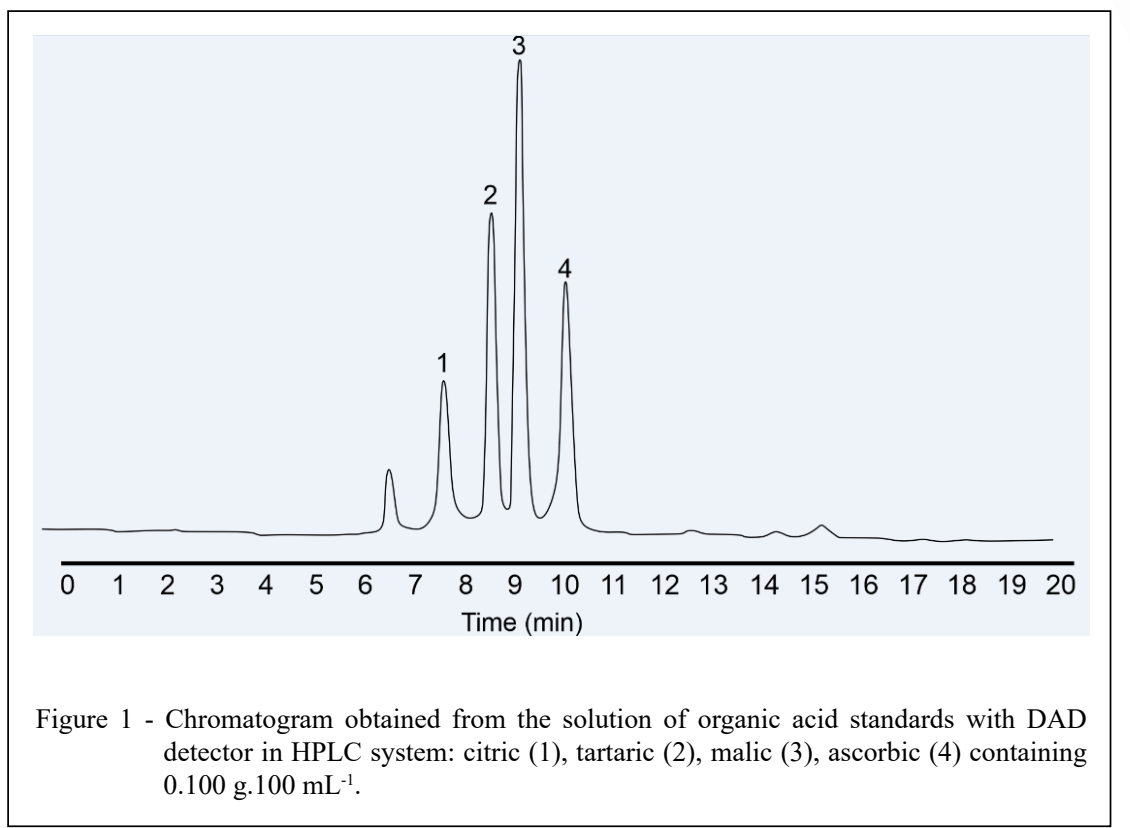

The use of the separation column together with the composition and flow of the mobile phase allowed for the adequate chromatographic separation observed in the chromatograms. Chromatographic signals for each studied compound were evidenced: citric, malic, ascorbic, tartaric and sucrose sugars, glucose and fructose, as well as the respective retention times, and the total time for the simultaneous analysis of the analytes was 20 minutes.

The order of elution of the standard compounds in the chromatogram indicated by Figures 1 and 2 reflect the different interactions between the analytes, stationary phase and mobile phase. DIAS (2014), in his study of the analysis of sugars and

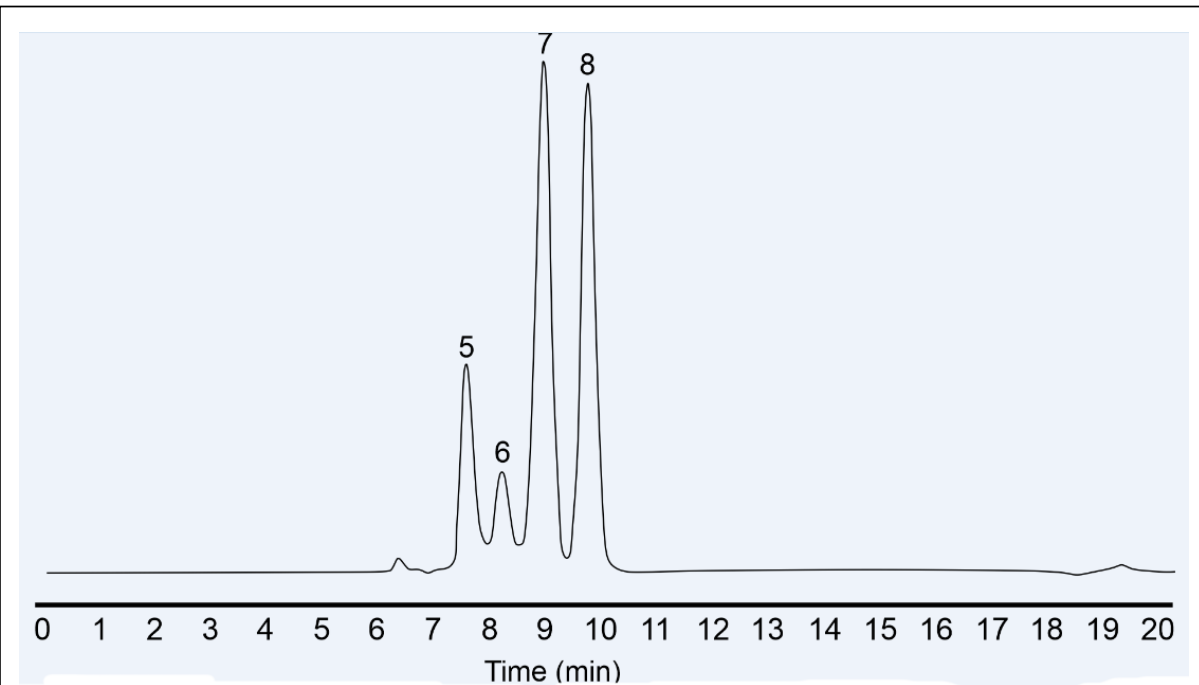

Figure 2 - Chromatogram obtained from sugar standard solution with RI detector in HPLC system: sucrose (5), unidentified peak (6), glucose (7) and fructose (8) containing $0.500 \mathrm{~g} . \mathrm{mL}^{-1}$ 
organic acids in commercial beverages (juices, nectars and soft drinks), he obtained the following order of elution: citric, malic and ascorbic (DAD detection) and sucrose, glucose and fructose (RI detection); therefore, similar to the one reported in this research.

The linearity ranges for the sugars were: 0.0025 to $0.5 \mathrm{~g} .100 \mathrm{~mL}^{-1}$ for fructose and sucrose and for glucose was 0.005 to $0.5 \mathrm{~g} .100 \mathrm{~mL}^{-1}$ for the organic acids 0,0002 at 0.1 g. $100 \mathrm{~mL}^{-1}$ for citric, 0.0002 at 0.04 g. $100 \mathrm{~mL}^{-1}$ for tartaric, 0.0025 at $0.05 \mathrm{~g} .100 \mathrm{~mL}^{-1}$ for ascorbic and 0.001 at $0.05 \mathrm{~g} .100 \mathrm{~mL}^{-1}$ for malic.

The chromatographic method was validated using parameters such as linearity, limit of detection (LOD), limit of quantification (LOQ), repeatability and intermediate precision. The results of such validation parameters are shown in table 2 .

The values for the correlation coefficient of each analyte were higher than 0.9900 , except for malic acid which was 0.9840 , which were considered suitable for analytical purposes. The lowest values of LOD and LOQ were reported for citric and tartaric acids and they demonstrated the great sensitivity of the detector. In general, sugars have higher limits (LOD; LOQ) than organic acids, this is probably due to the higher system noise level and the use of different detectors.

The coefficient of variation values for repeatability ranged from 0.188 to $6.716 \%$, while for intermediate precision from 0.424 to $8.833 \%$ (Table 3 ). Larger percentages were reported for intermediate accuracy, except for citric acid, and are justified by performing the analyzes with different analysts and on different days of the week; however, the observed values agree with studies of the same purpose (LEMOS et al., 2010).
In addition, when comparing coefficients of variation for repeatability and intermediate accuracy, remarkably higher values for organic acids are observed, this may be a consequence of the stability of the acids upon handling. However, estimates for coefficient of variation were below $8.833 \%$ suggesting a high precision of the method, according to the literature values below $15 \%$ are acceptable (PINTO \& JARDIM, 2000; AQUINO et al., 2004).

LIMA et al. (2010) in their study of organic acids determination in wines, optimized and validated a methodology using reverse phase HPLC for the simultaneous detection of tartaric, malic, lactic, citric and succinic acids. They obtained correlation coefficients also above 0.9900 and maximum limits of detection and quantification in the range of 0.0054 and 0.0031 g. $100 \mathrm{~mL}^{-1}$ respectively. The authors obtained between $0.30 \%$ and $6.93 \%$ of repeatability expressed as percentage of coefficient of variation, which resemble those determined in this research.

In this context, SANTOS et al. (2014) validated a method for the determination of tartaric, ascorbic, citric and fumaric acids in frozen fruit pulps using reverse phase HPLC. They obtained values of correlation coefficient also above 0.99 for the four acids and the repeatability ranged from $12.6 \%$ to $19.6 \%$, while the intermediate precision had its maximum value in $19.5 \%$.

CORRÊA et al. (2013) worked on the detection of sugars sucrose, fructose and glucose in grape juice and wine using HPLC and Rezex RHM column. The validation of the method showed good results, the correlation coefficients were above 0.99 , the detection limits were in the range of 0.0003 to

Table 3 - Results of the validation parameters of the analysis of organic acids and sugars by HPLC.

\begin{tabular}{|c|c|c|c|c|c|c|}
\hline Analytes & $\mathrm{R}^{2}$ & Linear equation & $\begin{array}{c}\text { LOD } \\
\left.\text { (g. } 100 \mathrm{~mL}^{-1}\right)\end{array}$ & $\begin{array}{c}\text { LOQ } \\
\text { (g. } 100 \mathrm{~mL}^{-1} \text { ) }\end{array}$ & $\begin{array}{c}\text { REP } \\
(\% \mathrm{CV})\end{array}$ & $\begin{array}{l}\text { PREC } \\
(\% \mathrm{CV})\end{array}$ \\
\hline Citric acid & 0.997 & $0.029 x+0.269$ & 0.0001 & 0.0025 & 6.716 & 2.530 \\
\hline Tartaric acid & 0.998 & $0.046 x-0.011$ & 0.0007 & 0.0022 & 1.472 & 3.682 \\
\hline Ascorbic acid & 0.993 & $0.036 x-0.426$ & 0.0020 & 0.0039 & 3.716 & 4.144 \\
\hline Malic Acid & 0.984 & $0.039 x-0.674$ & 0.0025 & 0.0043 & 2.959 & 8.833 \\
\hline Sucrose & 0.994 & $0.002 x-0.020$ & 0.0139 & 0.0443 & 0.207 & 1.935 \\
\hline Glucose & 0.998 & $0.005 x+0.267$ & 0.0006 & 0.0147 & 0.188 & 3.446 \\
\hline Fructose & 0.999 & $0.005 x-0.027$ & 0.0062 & 0.0189 & 0.226 & 0.424 \\
\hline
\end{tabular}

LOD: detection limit; LOQ: quantification limit; REP: Repeatability; PREC: Intermediate precision; \% CV: (standard deviation / mean) $\mathrm{x} 100$. 
0.0005 g.100 $\mathrm{mL}^{-1}$ and quantification of 0.0010 to $0.0015 \mathrm{~g} .100 \mathrm{~mL}^{-1}$, results close to those of the present study.

Additionally, SCHERER et al. (2008) validated a method of simultaneous determination of tartaric, malic, ascorbic and citric acids in cashew juice and cashew, acerola and açai pulps using HPLC. Results were promising, since $\mathrm{R}^{2}$ was above 0.99 , and repeatability ranged from 0.4 to $2.3 \%$, with an intermediate precision ranging from 1.2 to $5.0 \%$.

The main differential of the proposed chromatographic method has to do with the capacity of simultaneous determination of organic acids and sugars in short intervals (in the order of $11 \mathrm{~min}$ ), allowing greater analytical efficiency in relation to traditional chromatographic methods. It is important to mention that few studies applied to juice analysis carry out simultaneous determination, and even so, require longer analysis times. For example, COELHO et al. (2018) reported chromatographic analysis time of the order of 20 minutes in HPLC method applied to the simultaneous determination of organic acids and sugars in grape juices.

\section{Juice analysis}

The proposed method of chromatographic analysis was able to identify and quantify the organic acids and sugars in juice samples, since all samples were above the limit of detection and quantification reported in the chromatographic analysis (Table 3 ).

Table 4 shows that the concentration of ascorbic acid ranged from 0.177 to 0.505 g. 100 $\mathrm{mL}^{-1}$, being reported only in orange and mandarin juices, which obtained values significantly different from each other by Tukey's test. Similarly, BARCIA et al. (2010) analyzed several fruits and verified the presence of ascorbic acid in pears $\left(0.061 \mathrm{~g} .100 \mathrm{~mL}^{-1}\right)$, peach $\left(0.217 \mathrm{~g} .100 \mathrm{~mL}^{-1}\right)$ and passion fruit $(0.241 \mathrm{~g} .100$ $\left.\mathrm{mL}^{-1}\right)$. However, in the present study, ascorbic acid was notreported in apple and grape juices, possibly due to its oxidation, affected both by the presence of oxygen and by temperature, light and $\mathrm{pH}$ (TARRAGOTRANI, 2012). Analyzing the contents of citric acid it was observed its presence in all the samples studied. In relation to the concentration, a variation of 0.01 to $1.25 \mathrm{~g} .100 \mathrm{~mL}^{-1}$ was observed. All samples were above the limits of detection and quantification. The fact that all samples contain citric acid is indicative that industries could be adding it as a preservative and acidulant. In this context, KELEBEK et al. (2009) analyzed citric acid in grape juice and obtained the mean concentration concordant with those obtained in the present study (mean of 22 g. $100 \mathrm{~mL}^{-1}$ ). In addition, the Tukey's test reveals differentiation between two groups, grape and apple, and orange and tangerine, with the latter having significantly higher levels of acidulant, possibly for taste adjustment of the juice that is typically more acidic.

The concentration of malic acid was determined in all samples analyzed and the contents ranged from 0.260 to $0.525 \mathrm{~g} .100 \mathrm{~mL}^{-1}$, but no significant differences were reported between the contents of the juice varieties (Table 4). Furthermore, KELEBEK et al. (2009) working with grape juice determined malic acid at the concentration of $0.106 \mathrm{~g} .100 \mathrm{~mL}^{-1}$.

Table 4 shows that the concentrations of tartaric acid ranged from 0.0067 to $0.373 \mathrm{~g} .100 \mathrm{~mL}^{-1}$, and no sample was below detection and quantification limits. Acid detection occurred in all analyzed samples. The highest content was reported in grape juice, in which tartaric acid is the predominant acid, and the levels found differed significantly from those observed in the apple, orange and mandarin samples. The acidity of the grape at maturity is mainly due to tartaric, malic and citric acids (BLOUIN; GUIMBERTEAU, 2000). The L (+) isomer of tartaric acid is generally reported in a few plant species, but is present in significant concentrations in the vine. (PEYNAUD, 1947; CHAMPAGNOL, 1984; FAVAREL, 1994).

Table 4 - Results of the analysis of organic acids and sugars by HPLC in $\mathrm{g} 100 \mathrm{~mL}^{-1}$.

\begin{tabular}{|c|c|c|c|c|c|c|c|c|c|c|c|c|c|}
\hline \multicolumn{2}{|c|}{-------Ascorbic------- } & \multicolumn{2}{|c|}{-----Citric----- } & \multicolumn{2}{|c|}{-------Malic------- } & \multicolumn{2}{|c|}{---------Tartaric------- } & \multicolumn{2}{|c|}{----Sucrose----- } & \multicolumn{2}{|c|}{----Glucose---- } & \multicolumn{2}{|c|}{---Fructose--- } \\
\hline $\mathrm{Gr}$ & $0.000^{\mathrm{c}}$ & Ap & $0.01^{\mathrm{b}}$ & Or & $0.260^{\mathrm{a}}$ & Or & $0.0067^{b}$ & $\mathrm{Gr}$ & $0.232^{\mathrm{c}}$ & $\mathrm{Ta}$ & $3.310^{\mathrm{b}}$ & $\mathrm{Ta}$ & $3.520^{\mathrm{b}}$ \\
\hline Ap & $0.000^{\mathrm{c}}$ & $\mathrm{Gr}$ & $0.14^{\mathrm{b}}$ & $\mathrm{Ta}$ & $0.275^{\mathrm{a}}$ & $\mathrm{Ta}$ & $0.010^{\mathrm{b}}$ & Ap & $2.060^{\mathrm{b}}$ & Or & $3.390^{\mathrm{b}}$ & Or & $4.835^{\mathrm{b}}$ \\
\hline Or & $0.177^{\mathrm{b}}$ & Or & $0.98^{\mathrm{a}}$ & Gr & $0.375^{\mathrm{a}}$ & Ap & $0.065^{\mathrm{b}}$ & Or & $4.365^{\mathrm{a}}$ & Ap & $4.610^{\mathrm{b}}$ & $\mathrm{Gr}$ & $8.340^{\mathrm{a}}$ \\
\hline $\mathrm{Ta}$ & $0.505^{\mathrm{a}}$ & $\mathrm{Ta}$ & $1.25^{\mathrm{a}}$ & Ap & $0.525^{\mathrm{a}}$ & $\mathrm{Gr}$ & $0.373^{\mathrm{a}}$ & $\mathrm{Ta}$ & $4.560^{\mathrm{a}}$ & $\mathrm{Gr}$ & $8.070^{\mathrm{a}}$ & Ap & $10.47^{\mathrm{a}}$ \\
\hline
\end{tabular}


The presence of sucrose ranged from 0.232 to $4.560 \mathrm{~g} .100 \mathrm{~mL}^{-1}$, and the lowest sugar contents were found in the grape samples (Table 4). In this case, from the Tukey's test, three levels of differences between the concentrations were observed, and orange and mandarin did not differ among them, but they differed from grape and apple juices, and the latter differed from each other. The contents of these grape juice samples are in agreement with RIBÉREAU-GAYON, Maujean and Dubourdieu (2004), which stated that sucrose can also be present in whole grape juice, but in low concentrations. The term "whole juice" is exclusive to the juice without adding sugars, and in its natural concentration. Quantitatively the main sugar reported in the samples analyzed by KELEBEK et al. (2009) was the sucrose in relation to glucose and fructose (5.934;

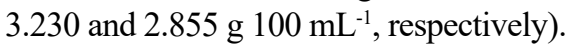

The glucose content in the samples obtained a great variation, as observed for the sucrose, being the variation of 3.310 to $8.07 \mathrm{~g} .100 \mathrm{~mL}^{-1}$. The highest measurements of glucose content were observed for whole grape juice. The only sample that differed statistically from the others was grape juice. These results agree with those obtained by CALDAS et al. (2015), who determined the concentrations of 4.59 and $5.10 \mathrm{~g} .100 \mathrm{~mL}^{-1}$ in two brands of grape nectars.

The fructose content varied from 3.52 to 10.47 g.100 $\mathrm{mL}^{-1}$ for mandarin and apple juices; respectively, and the apple and grape samples had the highest quantified levels, which did not differ from each other but differed statistically of the samples of tangerine and orange that presented relatively lower sugar concentration. CORRÊA et al. (2013) analyzed CLAE whole grape juice and obtained 7.23 and 7.52 g. $100 \mathrm{~mL}^{-1}$, values close to that reported in this study of grape juice $\left(8.34 \mathrm{~g} .100 \mathrm{~mL}^{-1}\right)$.

\section{Principal component analysis (PCA)}

By means of the Principal Component Analysis (PCA) represented by figure 3, which illustrates the graphs of scores and loadings, it is possible to infer which analytes are responsible for the observed distinction between the juice samples. This analysis proved to be effective in the present study because it presented an explanatory power of data variability in $85 \%$ (PC1 70.89\% and PC2 14.39\%).

Main component 1 (CP1), which has a strong explanatory power over the variability of the data, separates citrus juices from orange and mandarin, from grape and apple juices, whereas CP2 separates apple and orange juices from the others (Figure 3A). The Ap1 and Ap2 samples corresponding to the apple juice were also presented in an isolated way, being distinguished by the content of fructose and malic acid, predominant acid in the apple. While all grape juice (Gr1, Gr2, Gr3, Gr4, Gr5 and Gr6) form a large group due to the concentration of analytes tartaric acid, glucose and soluble solids (Figure 3B). Finally, the samples of orange juice and mandarin Or3, Or4, Ta1 and Ta2; respectively, stand out as the content of ascorbic and citric acids, which predominate in citrus fruits.

The orange juice represented by the Or1 and Or2 samples has a more significant vector for sucrose (figure 3B), sugar generally reported in
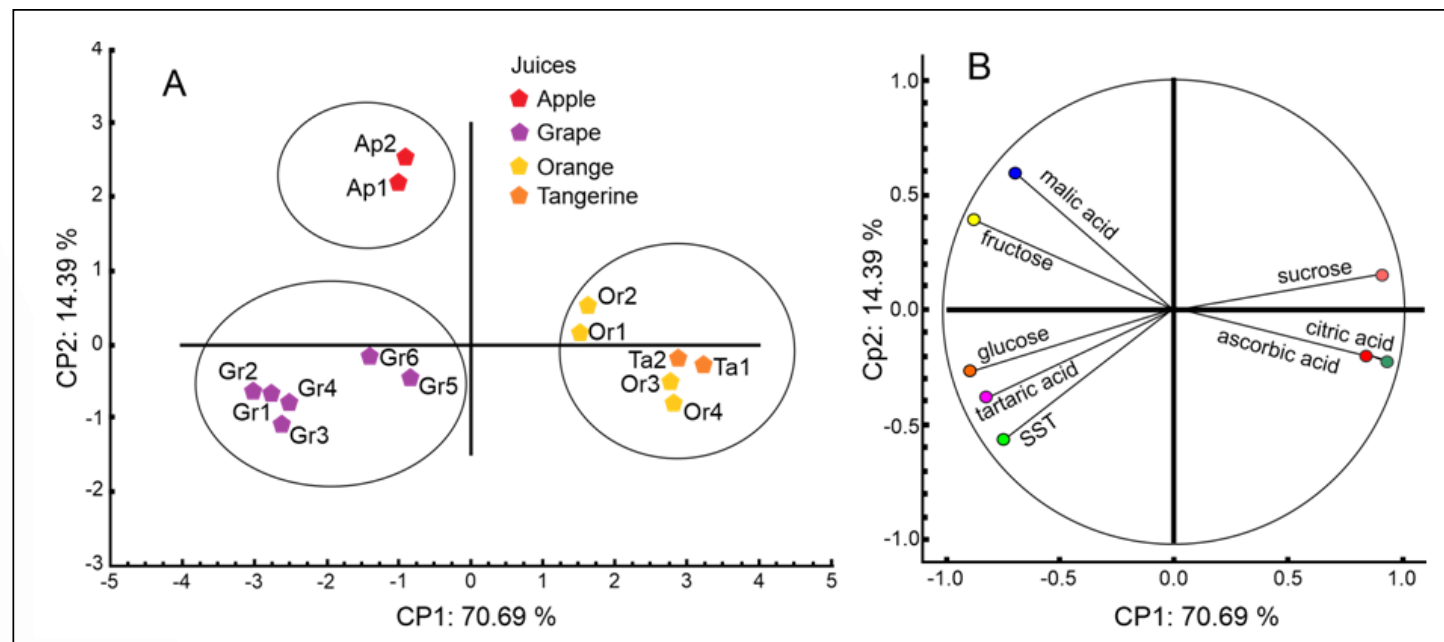

Figure 3 - Main component analyzes of data on sugars and organic acids: (A) loadings and (B) socores graphic. 
integral orange juices at low concentrations, due to its facilitated acidic hydrolysis, typical of citrus juices. It is interesting to note that, according to the legislation (BRASIL, 2018), sucrose should not be added in whole juices, an analysis of a larger set of samples, including control samples, could help in the identification of adulterations in commercial juices.

\section{CONCLUSION}

In the present study, the method developed and tested proved to be fast and efficient for the simultaneous determination of ascorbic, citric, malic and tartaric acids and sugars sucrose, glucose and fructose using HPLC. Their performance was confirmed by means of the coefficient of determination $\left(\mathrm{R}^{2}>0.98\right)$, low limits of detection and quantification, as well as low coefficients of variation for repeatability and intermediate precision $(\mathrm{CV}<8.83)$.

By means of the Tukey test, it wasreported that the orange and mandarin juices are very similar in relation to the determined contents of acids and sugars, since only for ascorbic acid their contents were statistically different, the other analytes did not differ. The test in question also revealed that malic acid concentrations did not differ in juice samples from the study.

The association of Principal Component Analysis (PCA) with the study of components present in commercial juices has demonstrated the potential for fraud detection, especially related to the use of sucrose. Finally, the quantification of the compounds under study in the fruit juices samples in the orange, grape, tangerine and apple flavors is useful for the evaluation and knowledge of the components present in routinely consumed beverages, as well as to understand the relationship between consumption and health.

\section{DECLARATION OF CONFLICT OF INTERESTS}

The authors declare no conflict of interest. The founding sponsors had no role in the design of the study; in the collection, analyses, or interpretation of data; in the writing of the manuscript, and in the decision to publish the results.

\section{AUTHORS' CONTRIBUTIONS}

The authors contributed equally to the manuscript.

\section{ACKNOWLEDGEMENTS}

The authors thank Coordenação de Aperfeiçoamento de Pessoal de Nível superior (CAPES - Brazil) and Universidade
Tecnológica Federal do Paraná (Edital No 08/2020 - DIRPPG-PB) by the financial support and the Central de Análises - UTFPR Campus Pato Branco for their analytical support.

\section{REFERENCES}

AQUINO, F. W. B. et al. Determination of additives, furanic aldehydes, sugars and caffeine in beverages by high performance liquid chromatographic: validation of methodologies. Ciência e Tecnologia de Alimentos, v.24, n.1, p.032-038, 2004. Available from: <https://www.scielo.br/scielo.php?script=sci arttext\&pid=S0101-20612004000100007\&lang=pt $>$. Accessed: Oct. 05, 2020. doi: 10.1590/S0101-20612004000100007.

BARCIA, M. T. et al. Determination by HPLC of ascorbic acid and tocopherols in fruits. Semina: Ciências Agrárias, v.31, n.2, p.381390, 2010. Available from: <http://www.uel.br/revistas/uel/index. php/semagrarias/article/view/5341>. Accessed: Oct. 05, 2020. doi: 10.5433/1679-0359.2010v31n2p381.

BLOUIN, J.; GUIMBERTEAU, G. Maturation et maturité des raisins. Bordeaux: Éditions Féret, p.151, 2000.

BORSANI, J. et al. Carbon metabolism of peach fruit after harvest: changes in enzymes involved in organic acid and sugar level Modifications. Journal of Experimental Botany, v.60, n.6, p.1823-1837, 2009. Available from:

$<$ https://academic.oup.com/jxb/article/60/6/1823/516686>. Accessed: Oct. 05, 2020. doi: 10.1093/jxb/erp055.

BRASIL. Agência Nacional de Vigilância Sanitária (ANVISA). Resolução RE nº 899, de 29 de maio de 2003. Guia para validação de métodos analíticos e bioanalíticos. Diário Oficial da União; Poder Executivo, de 02 de junho de 2003 . Available from: $<$ http://bvsms. saude.gov.br/bvs/saudelegis/anvisa/2003/res0899 29052003. html>. Accessed: Oct. 05, 2020.

BRASIL. Ministério da Agricultura, Pecuária e Abastecimento. IN No 49 DE 26/09/2018. Available from: <https://www.in.gov.br/ web/guest/materia/-/asset_publisher/Kujrw0TZC2Mb/content/ id/42586576/do1-2018-09-27-instrucao-normativa-n-49-de-26->. Accessed: Oct. 05, 2020.

CALDAS, B. S. et al. Comparative assessment of sugar in concentrated and nectar grape juices by refractometry, spectrophotometry and chromatography. Scientia Chomatographica, v.7, n.1, p.53-63, 2015. Available from: < http:// www.iicweb.org/scientiachromatographica.com/files/v7n1a03. pdf $>$. Accessed: Oct. 05, 2020. doi: 10.4322/sc.2015.016.

CHAMPAGNOL, F. Élements de physiologie de la vigne et de viticulture generale. Montpellier: DEHAN, p. 351, 1984.

CHINNICI, F. et al. Optimization of the determination of organic acids and sugars in fruit juices by ion-exclusion liquid chromatography. Journal of Food Composition and Analysis, v.18, n.2-3, p.121-130, 2005. Available from: <https://doi. org/10.1016/j.jfca.2004.01.005>. Accessed: Oct. 05, 2020.

COELHO, E. M. et al. Simultaneous analysis of sugars and organic acids in wine and grape juices by HPLC: Method validation and characterization of products from northeast Brazil, Journal of Food Composition and Analysis, v.66, p.160-167, 2018. Available from: <https://doi.org/10.1016/j.jfca.2017.12.017>. Accessed: Oct. 05, 2020. 
CORRÊA, L. C. et al. Sugar Determination in Grape Must, Juice and Wine by High Performance Liquid Chromatography (HPLC). Boletim de Pesquisa e Desenvolvimento, Embrapa Semiárido, 2013. Available from: <http://www.infoteca.cnptia.embrapa.br/ infoteca/handle/doc/981635>. Accessed: Oct. 05, 2020.

COSTA, M. P. et al. Simultaneous analysis of carbohydrates and organic acids by HPLC- DAD-RI for monitoring goat's milk yogurts fermentation. Talanta, v.152, p.162-170, 2016. Available from: <https://doi.org/10.1016/j.talanta.2016.01.061>. Accessed: Oct. $05,2020$.

DEMIATE, I. M. et al., Analysis of total and reducing sugar infoods. A comparative study betweencolorimetric and titration techniques. Publicitário UEPG - Ciênicas Exatas e da Terra, Ciências Agrárias e Engenharias, v.8, n.1, p.65-78, 2002. Available from: <https://revistas2.uepg.br/index.php/exatas/ article/view/772>. Accessed: Oct. 05, 2020. doi: 10.5212/ publicatio.v8i01.772.

DE OLIVEIRA, G. A. et al. Comparison of NIR and MIR spectroscopic methods for determination of individual sugars, organic acids and carotenoids in passion fruit. Food Research International, v.60, p.154-162, 2014. Available from: $<$ https://doi org/10.1016/j.foodres.2013.10.051>. Accessed: Oct. 05, 2020.

EYÉGHÉ-BICKONG, H, A. et al. Optimisation of an HPLC method for the simultaneous quantification of the major sugars and organic acids in grapevine berries. Journal of Chromatography B, v.885-886, p.43-49, 2012. Available from: $<$ https://doi.org/10.1016/j.jchromb.2011.12.011>. Accessed: Oct. 05,2020 .

FAVAREL, J. L. L'acidité tartrique et l'acidité: du moût au vin. In: LALLEMAND. La microbiologie des vins mousseux: la stabilisation des vins: mecanismes et evaluation. Toulouse, p.8794, 1994.

FERREIRA, D. F. Sisvar: A computer statistical analysis system. Ciência e Agrotecnologia (UFLA), v.35, n.6, p.10391042, 2011. Available from: <https://doi.org/10.1590/S141370542011000600001>. Accessed: Oct. 05, 2020.

HORTIFRUTI BRASIL ANUÁRIO 2019-2020. São Paulo: CEPEA, 2019. ISSN 1981-1837. Available from: <https://www. hfbrasil.org.br/br/revista/acessar/completo/anuario-2019-2020retrospectiva-2019-perspectivas-2020-dos-hf-s.aspx>. Accessed: Oct. 05, 2020.

KELEBEK, H. et al. HPLC determination of organic acids, sugars, phenolic compositions and antioxidant capacity of orange juice and orange wine made from a Turkish cv. Kozan. Microchemical Journal, v.91, n.2, p.187-192, 2009. Available from: $<$ https://doi. org/10.1016/j.microc.2008.10.008>. Accessed: Oct. 05, 2020.

KRITSUNANKUL, O.; et al., Flow injection on-line dialysis coupled to high performance liquid chromatography for the determination of some organic acids in wine. Talanta, v.79, n.4, p.1042-1049, 2009. Available from: <https://doi.org/10.1016/j. talanta.2009.03.001>. Accessed: Oct. 05, 2020.

LEMOS, G. S.; et al., Method validation to $\mathrm{hmf}$ determination in honey by HPLC-UV and its influence on the product quality. Química Nova, v.33, n.8, p.1682-1685, 2010. Available from: $<$ https://doi.org/10.1590/S0100-40422010000800012>. Accessed: Oct. $05,2020$.
LIMA, L. L. A. et al. Optimization and validation method for organic acid determination in wines by high Performance liquid cromatography. Química Nova, v.33, n.5, p.1186-1189, 2010. Available from: <http://dx.doi.org/10.21577/01004042.20170558>. Accessed: Oct. 05, 2020.

LIMA, M. S. et al. Phenolic compounds, organic acids and antioxidant activity of grape juices produced from new Brazilian varieties planted in the Northeast Region of Brazil. Food chemistry, v.161, n.15, p.94-103, 2014. Available from: $<$ https://doi.org/10.1016/j.foodchem.2014.03.109>. Accessed: Oct. 05, 2020.

PEYNAUD, E. Étude sur les acides organiques du raisin et du vin. Bulletin de l'OIV, Paris, v.20, n.191, p.34-51, 1947.

PINTO, G. M. F.; JARDIM, I. C. S. F. Use of solid-phase extraction and high - performance liquid chromatography for the determination of triazine residues in water: validation of the method. Journal Chromatografic, v.869, p.463-469, 2000. Available from: $<$ https://doi.org/10.1016/S0021-9673(99)01242-X>. Accessed: Oct. 05,2020

RANGEL, C. N. et al. Nutritional value of organic acid lime juice (Citrus latifoliaT.), cv. Tahiti. Ciência e Tecnologia de Alimentos, v.31, n.4, p. 918-922, 2011. Available from: <https:// doi.org/10.1590/S0101-20612011000400014>. Accessed: Oct. 05,2020 .

RIBÉREAU-GAYON, P; MAUJEAN, A.; DUBOURDIEU. Traité d'oenologie: chimie du vin, stabilization et traitements. 5. éd. Paris: Dunod, 2004

RIZZON, L. A.; SGANZERLA, V. M. A. Tartaric and malic acids in the must grapes of Bento Gonçalves-RS, Brazil. Ciência Rural, v.37, n.3, p.911-914, 2007. Available from: <http:// dx.doi.org/10.1590/S0103-84782007000300053>. Accessed: Oct. 05, 2020.

SANTOS, J. S.; et al., Validation of method for simultaneous determination of four organic acids in frozen fruit pulp by high performance liquid chromatography. Química Nova, v.37, n. 3, p.540-544, 2014. Available from: $<$ http://dx.doi.org/10.5935/01004042.20140087>. Accessed: Oct. 05, 2020.

SCHERER, R.;et al.,. Simulataneous determination of tartaric, malic, ascorbic and citric acids in acerola, açai and cashew pulps, and stability evaluation in cashew juices. Química Nova, v.31, n.5, p.1137-1140, 2008. Available from: <http:// dx.doi.org/10.1590/S0100-40422008000500039>. Accessed: Oct. 05,2020 .

DIAS, L. G.; SEQUEIRA, C.; VELOSO, A. C. A.; MORAIS, J. S.; SOUSA, M. E. B. C.; PERES, A. M. A Size Exclusion HPLC Method for Evaluating the Individual Impacts of Sugars and Organic Acids on Beverage Global Taste by Means of Calculated Dose-Over-Threshold Values. Chromatography, v.1, p.141-158, 2014. Available from: <https://www.mdpi.com/22279075/1/3/141/htm>. Accessed: Oct. 05, 2020. doi: 10.3390/ chromatography 1030141 .

TARRAGO-TRANI, M. T.; PHILLIPS, K. M.; COTTY, M. Matrixspecific method validation for quantitative analysis of vitamin C in diverse foods. Journal of Food Composition and Analysis, v.26, p.12-25, 2012. Available from: <https://doi.org/10.1016/j. jfca.2012.03.004>. Accessed: Oct. 05, 2020. 
XIE, L. et al. Quantification of glucose, fructose and sucrose in bayberry juice by NIR and PLS. Food Chemistry, v.114, p.1135-1140, 2009. Available from: <https://doi.org/10.1016/j. foodchem.2008.10.076>. Accessed: Oct. 05, 2020.

ZAKY, A. S. et al. A new HPLC method for simultaneously measuring chloride, sugars, organic acids and alcohols in food samples. Journal of Food Composition and Analysis, v.56, p.25-33, 2017. Available from: <https://doi.org/10.1016/j. jfca.2016.12.010>. Accessed: Oct. 05, 2020.

ZIELINSKI, A. A. F.; et al., Development and optimization of a HPLCRI method for the determination of major sugars in apple juice and evaluation of the effect of the ripening stage. Food Science and Technology, Campinas, v.34, p.38-43, 2014. Available from: $<$ https:// doi.org/10.1590/S0101-20612014005000003>. Accessed: Oct. 05, 2020. 